\title{
Constitutionalism: Negative AND Positive
}

\section{N. W. BARBER ${ }^{*}$}

Constitutionalism is a term that is often found in the title of books and articles, but is rarely considered in their texts. By and large, it is assumed that we know what constitutionalism entails, and that there is no need to examine it further. Constitutionalism is treated as a synonym for the legal enforcement of constitutional rules, or - perhaps - a subset of those rules; it is regarded as a desirable, maybe even a necessary, feature of a constitutional order. Attention swiftly turns to the practical difficulties involved in ensuring the effectiveness of these legal constraints. This paper challenges this simple understanding of constitutionalism, arguing those who see constitutionalism entirely in terms of constraints on state power miss an important aspect of the doctrine. Constitutionalism also requires the creation of an effective and competent set of state institutions; it has a positive dimension.

The examination of constitutionalism will proceed in three stages. First, the common understanding of constitutionalism will be surveyed. This presents constitutionalism in largely negative terms: as a set of limits on the state. It will be argued that this understanding of constitutionalism is unattractive as it fails to recognise the positive role that states play in our communities. State institutions may need to be limited, but they also need to be effective: able to help bring about the common good. This negative understanding of constitutionalism rests on an impoverished understanding of the nature of the state and, more over, leads to an impoverished understanding of the principles often associated with constitutionalism - such as the separation of powers and democracy. The second part of the paper will contend that the negative account of constitutionalism, though widely held, is not the only understanding available to us. Making use of Charles McIlwain's classic work on the subject - Constitutionalism: Ancient and Modern - it will be argued that there is an alternative, positive, understanding of constitutionalism that can found in the literature. In the third section of the paper it will be argued that this positive

\footnotetext{
${ }^{*}$ Trinity College, Oxford.
} 
conception of constitutionalism is attractive because it can be derived from a richer and more attractive account of the state and because, in its turn, it generates a richer and more attractive set of constitutional principles. The account of constitutionalism presented in this paper is, then, one that can be squared with much of the older literature on the topic, but one which is also more morally attractive than the simple negative accounts of constitutionalism that currently dominate academic discourse.

\section{Negative ConstitutionAlism}

The common understanding of constitutionalism - the one most often found in scholarly writing and, so far as it exists, the popular understanding of the doctrine outside of academia - treats constitutionalism in purely negative terms. Constitutionalism is equated with a demand for limited government. ${ }^{1}$ As Giovanni Sartori puts it, constitutionalism calls for restrictions on the arbitrary power of the state. $^{2}$ Others have tried to pin down these constraints with more precision. Perhaps constitutionalism binds the state to the rule of law and popular sovereignty, ${ }^{3}$ or to the separation of powers, ${ }^{4}$ or to the separation of powers and, also, to human rights. ${ }^{5}$

In addition to a commitment to some or all of these principles, it seems that these principles constrain the state in a particular type of way: through law, and, more specifically, through their application by judges. ${ }^{6}$ Constitutionalism requires judges

\footnotetext{
1 See the discussion in M. Loughlin, 'What is Constitutionalisation?' in P. Dobner and M. Loughlin, The Twilight of Constitutionalism? (Oxford: Oxford University Press, 2010), 55-58 and T. R. S. Allan, The Sovereignty of Law (Cambridge: Cambridge University Press, 2013), 17.

2 G. Sartori, 'Constitutionalism: A Preliminary Discussion' (1962) 56 The American Political Science Review 853, 855. See also M. J. C. Vile, Constitutionalism and the Separation of Powers $2^{\text {nd }}$ ed. (Indianapolis: Liberty Fund, 1998), 8-9.

3 G. J. Schochet, 'Introduction: Constitutionalism, Liberalism, and the Study of Politics' in J. R. Pennock and J. W. Chapman eds., Nomos XX: Constitutionalism (New York: New York University Press, 1979) 1, 4. See also J. Murkens, (2009) 29 Oxford Journal of Legal Studies 427, 444.

4 E. Barendt, 'Is There a United Kingdom Constitution?' (1997) 17 Oxford Journal of Legal Studies $137,141$.

5 J. Lane, Constitutions and Political Theory (Manchester: Manchester University Press, 1996), 25.

6 C. H. McIlwain, Constitutionalism: Ancient and Modern (New York: New York University Press, 1947), 21; M. Klarman, 'What's So Great About Constitutionalism?' (1998) 93 North Western University Law Review 145; Murkens, note 3 above, 437.
} 
to possess and exercise the capacity to strike down acts of the state that run against these principles. On some accounts of constitutionalism, strong-form judicial review - where the courts possess the power to declare acts of the legislature to be unconstitutional - is a necessary feature of the doctrine. ${ }^{7}$ Constitutionalism requires the legal realm to limit and regulate the political. Relatedly, sometimes a connection is sometimes drawn between constitutionalism and entrenchment. ${ }^{8}$ Not only do judges enforce these principles against state bodies but constitutionalism also requires that the capacity of the legislature to override judicial decisions, or to amend the constitution to alter the scope of judicial power, is constrained. The strictures of constitutionalism, it seems, apply to the legislature as well as to the executive.

Those who conceive of constitutionalism in purely negative terms might do so because of their conception of the state. Most contemporary accounts of the state are - knowingly or unknowingly - indebted to that of Max Weber. For Weber, the state was 'a human community that (successfully) claims the monopoly of the legitimate use of force within a given territory'. This account of the state combines a particular type of claim - an assertion of legitimacy - with a particular method of social control - the exertion of force. ${ }^{10}$ The relationship between the state and its members starts from a position of domination, clothed in a claim to legitimacy. The state exerts power over its people and its territory, and when exercising this power it claims to be legitimate; asserting that those whom it commands ought to obey its dictates. But there is an important distinction between these two aspects. Whilst the state, to exist, must be able to secure the compliance of its people to some extent, its claims to legitimacy may be wholly false. Weber's conception of the state did not distinguish between flourishing democracies and oppressive dictatorships; each of these forms of

\footnotetext{
7 See, for example, Barendt, note 4 above, and see further Richard Bellamy's powerful critique of this position: R. Bellamy, Political Constitutionalism (Cambridge: Cambridge University Press, 2007), chapter 1 .

8 L. Alexander, 'Constitutionalism' in T. Christiano and J. Christman, Contemporary Debates in Political Philosophy (Oxford: Wiley-Blackwell, 2009).

9 M. Weber 'Politics as a Vocation' in H. H. Gerth and C. Wright Mills eds., From Max Weber: Essays in Sociology (Abingdon: Routledge, 1991), 78. See further N. W. Barber The Constitutional State (Oxford: Oxford University Press, 2010), chapter 2.

${ }^{10}$ For a contemporary version of Weber's model, see L. Green, The Authority of the State (Oxford: Clarendon Press, 1990), chapter 3.
} 
the state may be successful in commanding their people, each makes a claim to legitimacy. That the claim is more plausible in the first case than the second is, as regards our understanding of the state as an institution, irrelevant.

It is easy to imagine how a negative model of constitutionalism could emerge from this understanding of the state. The state is presented as an exercise of raw power, clothed in a claim to legitimacy; initially, at least, the state appears a threat to individuals, as a danger that needs to be constrained. The challenge of constitutionalism, on this model, is to find ways by which the state can be limited and the liberty of the individual protected; the role of law, applied by the courts, is to reign in the power of the state, to limit the dangerous capacities of the executive and legislative branches. On this understanding of the state and law it is - superficially plausible to talk of the constitution being imposed upon the state, as a set of rules that are applied to a pre-existing, distinct, social entity. ${ }^{11}$ To possess a constitution, to subscribe to constitutionalism, requires that law is imposed upon the state by the judges, leaving space for individuals to act, safe in the knowledge the coercive power of the state is constrained.

The negative model of constitutionalism then, in its turn, shapes our understandings of the principles of constitutionalism, providing a frame within which these principles are understood as limitations on the actions of the state. Many accounts of constitutional principles present them in negative terms. For instance, it is commonly argued that the purpose of separation of powers is to protect the liberty of the individual by making tyrannical and arbitrary state action more difficult. ${ }^{12}$ Power is divided between the branches of the constitution, with each element checking the others. As Justice Brandeis put it: the purpose of separation of powers 'was not to avoid friction, but, by means of the inevitable friction incident to the distribution of the governmental powers among three departments, to save the people

11 D. Grimm, 'Integration by Constitution' (2005) 3 International Journal of Constitutional Law 193, 194 and 204.

12 See, for example: E. Barendt, 'Separation of Powers and Constitutional Government' (1995) Public Law 599, 605-606; S. Calabresi and K. Rhodes, 'The Structural Constitution: Unitary Executive, Plural Judiciary' (1992) 105 Harvard Law Review 1153, 1156, where separation of powers is described as 'institutionalising conflict'. 
from autocracy. ${ }^{13}$ Concerted state action is made harder by the existence of checks and balances between the various organs of state. ${ }^{14}$ For the state to act, agreement is needed between a number of institutions staffed by a range of different people; the constitutional structure required by the separation of powers consequently slows down the state, acting as a brake on state action.

These last few paragraphs were carefully worded. There is no necessary connection between negative constitutionalism, the Weberian model of the state, and an understanding of constitutional principles that presents them as limitors. Many theorists, tempted by one or other of these three, would not draw the connection, treating constitutionalism, the state, and constitutional principles as unconnected entities. But there is a coherence to this account of constitutional theory - and perhaps it is reasonable to assume that these features would cohere: that our understanding of the state would inform our understanding of constitutionalism, and that these would, in their turn, shape our account of principles such as the separation of powers.

This conception of constitutionalism, what I have termed negative constitutionalism, has come in for some trenchant criticism in recent years. Perhaps most notably, Jeremy Waldron has argued that this model of constitutionalism is fundamentally flawed. ${ }^{15}$ Waldron claims that this version of constitutionalism, enforced by the judges and protected by some level of entrenchment, is allied with a narrow political ideology: a form of minimal-state liberalism. For example, this understanding of constitutionalism serves to make it harder for a state to create a system of healthcare or undertake schemes to alleviate poverty. Negative constitutionalism requires an institutional structure that prevents, or inhibits, the state from pursuing projects that aim to improve the lives of its people. This may be desirable if all you want of the state is that it leave you alone, but it is frustrating if you want the state to aid you in some way. Waldron consequently critiques

\footnotetext{
${ }^{13}$ Myers v US (1926) 272 U.S. 52, 293.

${ }^{14}$ M. Vile, Constitutionalism and the Separation of Powers, $2^{\text {nd }}$ ed.,(Indianapolis: Liberty Press, 1998), 14.

15 J. Waldron, 'Constitutionalism - A Skeptical View' in T. Christiano and J. Christman, Contemporary Debates in Political Philosophy (Oxford: Wiley-Blackwell, 2009), and Bellamy, note 7 above.
} 
constitutionalism for its anti-democratic tendencies: if minimal-state liberalism is to be adopted by a community, its advocates should have to win their case within democratic forums, not by constitutional fiat. Negative constitutionalism prioritises one political position over others, and so runs against the egalitarianism that Waldron identifies as at the heart of democracy.

The anti-democratic aspect of negative constitutionalism is certainly one problem with this model, but it is far from its only failing. Negative constitutionalism builds upon, or implies, an impoverished account of the state. The Weberian model of the state, discussed earlier, captures the characteristic authority claims that the institution levels, but fails to place the state in a broader moral context. An ambitious alternative to this account, following Aristotle's lead, would argue that the purpose of the state is an aspect of its nature ${ }^{16}$ the state should be understood as characterised both by its technique and by its point. Aristotle drew the defining purpose of the state broadly: it exists to advance the well-being of its members. A state that fails to advance its people's well-being is not merely a state that acts badly, but an institution that has failed to achieve its defining point, like a hospital that fails to treat the sick or a prison that fails to confine criminals. A more modest reply to the Weberian model would accept that the state has the attributes this account identifies, but go on to argue that given the capacities of the state, it ought to act towards good ends. The state has the capacity to advance the well-being of its members and, even if this objective is not an aspect of its nature, it should still seek to act in a morally attractive manner.

Weber, and those who write in his tradition, succeeded in identifying part of the nature of the state - its distinctive mode of action - but fail to locate this mode of action within a wider understanding of the state's purpose. A richer understanding of the state, one that brings forward its purpose or potential, illuminates a further and more profound problem with negative constitutionalism. Negative constitutionalism is in tension with the point of the state; calling for an institutional structure that would make it harder for the state to benefit its people. Like the Weberian model of the state, negative constitutionalism has only captured part of the story. Just as the state

\footnotetext{
16 As I have argued: N. W. Barber The Constitutional State, (Oxford: Oxford University Press, 2010), chapters 1 and 2 .
} 
is only partly characterised by its wide authority claims and its capacity to effectively guide conduct, so too constitutionalism is only partly characterised by the need to limit the power of the state and guard against oppression.

\section{Positive Constitutionalism}

It might be argued that we should stop here; having identified the reasons why negative constitutionalism is unattractive, perhaps we should simply cease to make use of the concept. This seems to be Waldron's view: maybe we are better off without the term. But an alternative strategy would seek to rehabilitate constitutionalism, to find an understanding of constitutionalism that is morally attractive in itself and which, also, coheres with sounder understandings of both the state and constitutional principles.

A possible objection to such a project would be that it takes us too far away from the common understanding of constitutionalism. An interpretation of a doctrine such as constitutionalism needs to stay reasonably close to the common understanding in order to remain intelligible. ${ }^{17}$ An interpretation that strays too far might be criticised for not really being an account of constitutionalism at all - it might be confusing to insist on using this term for a very different concept. But, fortunately, the history of constitutionalism is rich enough to provide the resources for a very different version of the doctrine. Perhaps surprisingly, an alternative understanding can be identified within the classic, the seminal, work on constitutionalism: Charles Howard McIlwain's Constitutionalism: Ancient and Modern.

Waldron includes McIlwain as an example of negative constitutionalism, ${ }^{18}$ and, indeed, McIlwain invites this interpretation, emphasising that constitutionalism requires, at its heart, the legal limitation of government and opposition to arbitrary

\footnotetext{
17 On the significance of the common understanding, see N. W. Barber, 'The Significance of the Common Understanding in Legal Theory' (2016) 36 Oxford Journal of Legal Studies (forthcoming).

18 Waldron, note 15 above, at 271.
} 
rule. ${ }^{19}$ But there is more to McIlwain's account of constitutionalism than simply the limitation of government.

The title of Mcllwain's book suggests a dichotomy: that he proposes to contrast rival versions of constitutionalism - the ancient and the modern - and draw comparisons between them. In fact, McIlwain's project is to chart the emergence of the modern form of constitutionalism from its ancient origins and, rather than a dichotomy, he identifies a spectrum of forms of constitutionalism between these two positions. In a valuable paper Douglas Sturm identifies five successive stages in McIlwain's story, ${ }^{20}$ and doubtless other lines could be drawn. The starting point of constitutionalism - ancient constitutionalism - amounts to a stand against arbitrary rule. Perhaps the best interpretation of McIlwain's understanding of ancient constitutionalism is that it embodied a commitment to government according to moral rules, in opposition to the view that the powerful were entitled to exercise force whenever and however they chose to do so. McIlwain presents this as a commitment to natural law: ${ }^{21}$ ancient constitutionalism had no notion of using positive law to constrain and guide power. The earliest conceptions of the state were embedded within a broader political theory: the institution of the state was understood as part of a wider account of the proper ends of collective action. ${ }^{22}$ McIlwain charts the evolution of the doctrine into the Roman period, where the recognition of the moral aspect of the state was supplemented by the claim that the source of its authority was located in its people. ${ }^{23}$ Not only ought the state to act in the interests of its members, it was also an institution that enabled them, collectively, to act towards this goal. Between the Roman period and modern constitutionalism, states developed legal mechanisms to constrain the executive - the monarch - to the fundamental laws of the

\footnotetext{
19 McIlwain, note 6 above, 21.

20 D. Sturm, 'Constitutionalism: A Critical Appreciation and an Extension of the Political Theory of C. H. McIlwain’ (1969-70) 54 Minnesota Law Review 215.
}

21 McIlwain, note 6 above, 28. McIlwain is, of course, using the term 'natural law' in a far broader sense than most modern natural lawyers.

22 Aristotle, The Politics and Constitution of Athens, ed. S. Everson, (Cambridge: Cambridge University Press, 1996), I.II 1252b28-30; III.IX 1280b39-40. See also C. Johnson, Aristotle's Theory of the State (London: Macmillan, 1989), chapter 4, and J. Finnis, Aquinas (Oxford: Oxford University Press, 1998), chapter 7.

\footnotetext{
${ }^{23}$ McIlwain, note 6 above, chapter 3 .
} 
constitution. It came to be recognised that the executive was legally limited in its jurisdiction, ${ }^{24}$ and, moreover, that the democratic part of the constitution, Parliament, was the institution through which the people could determine the content of the law. ${ }^{25}$ By this stage, to steal an epigram, constitutionalism required government of the people, by the people, for the people.

The end point of McIlwain's journey, modern constitutionalism, requires far more than just the application of the law to the institutions of the state. It requires that the state possess a set of institutions that is able to act: a strong government. ${ }^{26}$ It further requires that these institutions are accountable to, and controlled by, the people they are intended to serve, requiring political processes of accountability to complement the legal side of the constitution. ${ }^{27}$ In short, for McIlwain, constitutionalism was not solely concerned with limiting the power of the state, but was rather concerned with creating an institutional structure that facilitated the successful functioning of the state. This does require limitations - there is certainly a demand that the courts apply the law to the executive - but it also required the creation of effective, powerful, institutions that interact in constructive, as well as constraining, ways.

McIlwain's book is a fine example of an exercise in intellectual history, teasing out the connections between the different and developing understandings of constitutionalism. It is weaker, though, if assessed as an interpretation of constitutionalism - that is, as an attempt to provide an attractive account of the doctrine, an interpretation that we have reason to endorse. The final version of constitutionalism that emerges from McIlwain's book is underdeveloped. McIlwain does not explain how the three core aspects of modern constitutionalism he identifies - that the state's authority is grounded in its people, that it acts for their benefit, and that the people exercise control over the state - interrelate. Superficially, they appear to be in tension. If the members of the state get to determine the rules of the

\footnotetext{
${ }^{24}$ Ibid., chapter 4.

${ }^{25}$ Ibid., chapter 5.

${ }^{26}$ Ibid., 144.

27 Ibid., 133.
} 
constitution, what confidence can we have that they will create institutions that can effectively advance their interests? And there seems to be a very obvious tension between empowering the people to determine the content of laws and ensuring those laws work for their benefit. What if the democratic processes of the state produce bad law and poor government? There may be ways of resolving these conundrums, but Mcllwain does not attempt to answer them.

Despite these limitations, the understanding of constitutionalism found in McIlwain points us towards a richer account of that doctrine. That the beginnings of such an account can be found in one of the classic, standard, works on constitutionalism shows that negative constitutionalism - discussed in the first third of this paper - is not the only understanding of the doctrine on offer. Waldron is right to argue that negative constitutionalism rest on a set of mistakes, but it is possible to formulate a better account of constitutionalism - positive constitutionalism - which draws on earlier writings on the topic. The common understanding of constitutionalism is flexible enough to allow us, intelligibly, to talk of positive constitutionalism as a superior interpretation of the doctrine when contrasted with its negative counterpart.

\section{CONSTITUTIONALISM: A FreSH START}

There are three connections that need to be considered in order to develop an attractive account of constitutionalism. First, there is the derivation of constitutionalism from an account of the state. A sound understanding of the state leads us towards a sound understanding of constitutionalism. Second, there is the connection between constitutionalism and constitutional principles. Constitutionalism is comprised of these constitutional principles; it is a doctrine that can be broken down into a number of discrete elements. Finally, completing the circle, there is a connection to be drawn between these principles and the state. By examining the principles that make up constitutionalism we gain a better understanding of the institutional structures that are required by a successful state.

(i) Deriving Constitutionalism From An Account of the State 
The state is not an institution every community should wish to create. Small communities can, sometimes, function perfectly well without it. A bunch of sailors ship-wrecked on an island or a tribal community do not need to create a state. Rather than relying on authority, these groups can make decisions through consensus. Each member can know every other member, and reputation - social capital - may be enough to ensure that the community functions successfully. There is no need for law, or for a formalised structure of coercion, in such groups. Indeed, creating such structures might be counter-productive: facilitating the domination of one part of the group over another.

In larger communities - communities like ours - the state is needed to coordinate and police people's conduct. Where we have reason to create the state, we have reason to create it with an institutional structure that enables it to achieve its defining purpose. Just as a person setting up a university should create it with the institutional capacities necessary to advance learning, or the founder of a hospital should endow that body with the structures that will enable it to treat the sick, the founder of a state should ensure that it possesses the institutional capacities necessary for the advancement of the well-being of its members. The same also applies to those acting within existing institutions: decisions about the running or structure of a university or hospital should, normally, be decisions that protect or enhance their capacity to function. Those acting within the state should also consider the impact of their actions on the functioning of the state: the effectiveness of the state requires continuing support. We have, then, a (moral) reason to create and support the state because it is necessary - in societies like ours - for our well-being.

Constitutionalism is a set of principles relating to the institutional structure of the state that is derived from the (moral) reason we have for wanting the state. The principles of constitutionalism are directed towards ensuring that the state possesses an institutional structure that has the capacity to effectively advance the well-being of its members. The connection between constitutionalism and the principles that it contains will be discussed further in the following section.

Two connections between the state and the advancement of the well-being of its members were discussed in the previous section. The first contended that this goal 
was an aspect of the nature of the state. The second contended that, given the capacities of the state, this was an end it ought to pursue. In each case, if we have reason to create the state we have reason to create it in a manner that enables it to pursue this end. For the purposes of this paper it does not matter which account is adopted: each drives us towards a positive conception of constitutionalism. But the first derivation of constitutionalism - which connects constitutionalism to the nature of the state - might be more faithful to the older literature on the doctrine. This is a connection made or implied by much of the literature on constitutionalism; a connection at the heart of the common understanding of the doctrine. On this account, constitutionalism is necessary not only in order for the state to achieve beneficial goals for its community but, also, in order for the state to succeed as a state. To return to the example discussed earlier, a prison that - somehow - had the capacity to improve the health of the community in which it was based might sometimes be right to pursue that goal, but no matter how successful it was in pursuing this end, it would not render it more successful as a prison. Constitutionalism is a doctrine that is morally attractive when having a state is morally attractive, but it is also a doctrine that is derived from the nature of the state, and would still be relevant for the state's success qua a state, even if we did not have reason to create the state in our community.

\section{(ii) Between Constitutionalism and its Principles}

Constitutionalism is a doctrine that is derived from, or at least tightly connected to, the state. It applies to those creating states and, also, to those who act within and upon the structures of the state. It is a collection of principles - though, as the discussion in the first part of this paper demonstrates, there is considerable disagreement about which principles should be included within the doctrine. To some extent this disagreement is misdirected: constitutionalism is more inclusive than many think. A number of the suggested principles are included within the doctrine: state sovereignty, the separation of powers, democracy - amongst others - are all aspects of constitutionalism.

The inclusivity of positive constitutionalism brings a worry: perhaps the account is too broad; perhaps we risk collapsing the whole of political philosophy into 
constitutionalism. Constitutionalism is certainly a subset of political philosophy, but the direct connection between the principles of constitutionalism, on the one hand, and the institutions and structures of the state, on the other, distinguishes these principles from other moral considerations that apply to individuals and groups. There are two aspects that serve to distinguish constitutionalism from other aspects of political philosophy. First, the principles of constitutionalism relate to the state - and to other bodies so far as they resemble the state. Other moral principles and obligations may also apply to the state, but these considerations are of wider application - often they are universally applicable, and are relevant to all groups and institutions. Secondly, the principles of constitutionalism have a distinctive structure. They present a state of affairs, a partial and idealised model of the state, that those addressed by the principles of constitutionalism are enjoined to create.

The principles of constitutionalism relate directly to the institutional structure of the state, but there are other, wider, moral principles that also help determine how the state should act. The demands of justice, for instance, apply in all communities. States ought to act justly, and ought also to ensure that their members treat each other in a just fashion. But the same is true for all other social groups: from families, though tribal groups, up to the international community, all of these bodies are bound to act justly, and all ought to apply the principles of justice. Similarly, at least some human rights are of general application. Everyone, for example, has a right not to be tortured, but this right binds interactions between individuals as much as it applies to interactions between the state and its people. Principles like justice and the moral obligations that instantiate human rights do apply to states, and do partly determine how states should act, but they do not directly address the institutional structure of the state. The principles of constitutionalism relate to the capacity of the state to achieve its goals, goals that might include fulfilment of these broader moral obligations; they are concerned with the types of institution that the state needs, and the relationships between those institutions.

An alternative objection would point to constitutionalism's life beyond the state: perhaps constitutionalism applies to other forms of institution as well. Many papers have been written discussing the role of constitutionalism in the context of the European Union, for example, or the international community. To the extent that 
these other institutions resemble the state, constitutionalism is applicable to them. If the European Union became a state, constitutionalism would apply to it with full force: the Union would require the institutions and structures that are required by the state. However, the European Union is not yet a state, and may never gain statehood. The differences between the European Union and the state explain and justify why constitutionalism does not apply directly to that body. Some aspects of constitutionalism are relevant: the Union should adhere to the rule of law and subsidiarity, for instance. Other aspects of constitutionalism are partly relevant: the separation of powers speaks to the interaction of the court with other bodies, and illuminates the position of the European Parliament. But other parts of the doctrine are pretty much irrelevant: the Union is not sovereign, and should not - yet - seek to become so.

Second, the principles of constitutionalism have a distinctive structure. Moral considerations apply directly to those they address. They give us reason to act, or not to act, in certain ways. The principles of constitutionalism stand between these moral reasons and actors. They provide an idealised, and partial, vision of the form the constitution should take, and then require those working within constitutions to pursue this ideal. So, for example, an aspect of the separation of powers is the requirement that the judiciary be independent of the executive branch. Structures are needed that enable the judge to decide cases between the executive and the citizen impartially. There are a host of values that ground this aspect of judicial independence. By rendering the application of the law more predictable, judicial independence helps protect the autonomy of citizens: people can take advantage of the rights and opportunities offered by the law, and know what actions they are required to avoid. This also helps individuals to create legal relationships with other private individuals - though the creation of contracts and companies - which allow them to pursue valuable projects within groups. And judicial independence can also be seen as a working through of the basic moral equality of persons in the constitutional sphere. The state official and the private citizens are treated as constitutional equals before the court: any special powers claimed by the official must be shown to be grounded in law and, ultimately, conferred by collective decision of the community. Much more could be said about why judicial independence is valuable, but the point is a relatively simple one. It is a mistake to talk of judicial 
independence as protecting a single value. There is a host of values that make judicial independence worthwhile: this one aspect of constitutionalism is justified by a range of different values.

The principles of constitutionalism depict a state of affairs we have reason to want to bring about. But the reasons for wanting this state of affairs are many and various. The principles of constitutionalism then act as rules, standing between the basic values that make life worthwhile and constitutional actors. When asserting that the desirability of judicial independence should guide constitutional change, or shape the conduct of officials, it is generally unnecessary to go back to ask why judicial independence was important in the first place. This mediating aspect of principles is commonly relied upon in their invocation in academic and popular discourse. People are enjoined to uphold the rule of law, or to respect the separation of powers. Multinationals and foreign governments are criticised for failing to honour the sovereignty of a state. In many cases, little is said about why the rule of law, the separation of powers, or state sovereignty, is valuable. They are treated as rules: it is unnecessary to constantly return to the reasons we have for embracing them.

The states of affairs specified by the principles of constitutionalism are ideals, but they are ideals that we have reason to pursue. In classical literature a divide is sometimes drawn between the theoretical ideal and the obtainable ideal. ${ }^{28}$ The theoretical ideal is one that we would pursue if we were unencumbered by limited abilities and capacities. In Aristotle's work, the example of kingship is given. ${ }^{29}$ Monarchy is an example of a theoretically ideal form of government; if we could find a person blessed with perfect good will and omniscience, we should make them king. But the golden age has ended, and such people no longer exist. Monarchy is then a theoretical, rather than obtainable, ideal. A common argument for the benefits of capitalism over communism takes a similar form. If people were altruistic, and had complete knowledge of the needs of their fellows, communism would be preferable to

\footnotetext{
28 On the distinction in Plato, see C. H. McIlwain, Constitutionalism: Ancient and Modern, rev. ed.,(New York: Cornell University Press, 1947), 27-35. On the distinction in Aristotle's work, see C. Johnson, Aristotle's Theory of the State, (London: Macmillan, 1990), 162-166.

29 Aristotle, The Politics and Constitution of Athens, ed. S. Everson, (Cambridge: Cambridge University Press, 1996), III.XIII, 1284b28-35.
} 
capitalism. But given our limited altruism and limited knowledge, capitalism is a better way of distributing resources within our society. Even if communism is the theoretical ideal, capitalism is the obtainable ideal.

There is a danger in pursuing the theoretical ideal rather than the obtainable ideal. $^{30}$ It is not necessarily the case that the obtainable ideal is simply a weaker version of the theoretical. Sometimes we will be worse off if we pursue the theoretical ideal rather than the obtainable. A state that pursued the theoretical ideal of monarchy would probably find itself with a dictatorship rather than the republic that Aristotle identifies as the obtainable ideal. Similarly, a state that pursued communism would probably end up with widespread corruption and the inefficient allocation of resources - far removed from the obtainable ideal of capitalism.

The principles of constitutionalism are, then, ideals, but obtainable ideals. They are ideals that take account of human limitations. It is highly unlikely that any state would ever completely satisfy the demands of constitutionalism, but it is at least possible. Some of the principles of constitutionalism present states of affairs that must, to some extent, be present in order for the state to exist. A polity that completely failed to achieve the demands of sovereignty, the rule of law, or the separation of powers, for instance, would not constitute a state at all. It would lack some of the necessary attributes of that institution. Other principles - such as democracy and subsidiarity - can be completely absent from a state without imperilling its identity as a state, but the failure of the polity to honour these principles will prevent the state from advancing the well-being of its people as fully as it otherwise could.

The principles of constitutionalism are also partial: they do not seek to produce a single model of constitution. Whilst they depict a state of affairs that states should seek to bring about, they are under-determinative. There are lots of ways that a state could pursue these principles, and lots of forms a state characterised by constitutionalism could take. This is partly because the institutional structure that a

\footnotetext{
30 Adrian Vermeule makes a related point about the dangers of changing elements of a system: A. Vermeule, The System of the Constitution (Oxford: Oxford University Press, 2011), 87-94.
} 
state should adopt is, to an extent, determined by the history and local circumstances of that state. In one state the courts might, for example, have a history of protecting citizens against oppressive executive decisions. In a second state, the courts might have acted to stall liberal legislation enacted by the legislature. The balance struck between the courts and other institutions should take account of this history. Similarly, a small state - like Iceland - may not require a federal structure to satisfy the demands of subsidiarity, whilst a large state - like America - clearly does require a constitutionally protected regional division of power. In addition to depending on these contingent factors, the principles of constitutionalism are also partial because there are a range of forms that can fulfil their demands. It is doubtful, for instance, that the presidential structure is always preferable to the parliamentary, or the parliamentary is always preferable to the presidential. Each realises the demands of constitutionalism in different ways.

It might be objected that the principles of constitutionalism, understood in this way, are of limited utility. If they stand in between the values that we should pursue and the reasons that apply to actors, can they not be safely eliminated from our account of the constitution? Perhaps Occam's Razor applies: we should reason directly from values to institutional structures without making use of these intermediate principles. Arguments of this type are common in constitutional theory. The separation of powers, it has been said, is 'a jumbled portmanteau of arguments for policies which ought to be supported or rejected on other grounds, ${ }^{31}$ whilst the rule of law, it has been claimed, is virtually meaningless. ${ }^{32}$ However, there are a number of reasons why it is useful to talk about the principles of constitutionalism, rather than ignoring them in favour of the values that underpin them.

First, and most superficially, it is worth examining the principles of constitutionalism because they are features of our constitutional discourse. People commonly regard these principles as binding and, to an extent, this belief is self-

\footnotetext{
${ }^{31}$ G. Marshall, Constitutional Theory (Oxford: Clarendon Press, 1971), 124.

32 J. N. Shklar, 'Political Theory and the Rule of Law' in A. C. Hutchinson and P. Monahan, eds., The Rule of Law: Ideal or Ideology? (Toronto: Carswell, 1987); M. Loughlin, Foundations of Public Law (Oxford: Oxford University Press, 2010), 314; J. Hasnas, 'The Myth of the Rule of Law' (1995)

Wisconsin Law Review 199
} 
fulfilling. Because the community believes that these principles should be honoured, those acting within constitutional structures are pressured towards obedience. These principles are often manifested in social rules - or conventions - that affect how power within the state is exercised. To claim, for instance, that a proposed action violates the principle of the separation of powers, or imperils state sovereignty, is often to criticise the actor for breaking a constitutional rule. In the United Kingdom, for instance, the removal of the Lord Chancellor's judicial role was justified by the invocation of the separation of powers: ${ }^{33}$ for a person to hold office in both the executive and judicial branch was thought to violate the principle. Which principles are embraced by the community and are then effective within the constitution will vary from state to state. In China, for example, there is broad agreement that the rule of law and state sovereignty are principles that must be respected, but the separation of powers is often regarded as antithetical to the state - and subsidiarity runs against the strong centralist ideology that underpins the constitution. Sometimes the principles of constitutionalism are found within the law of the state. They may be contained within the constitution, in statutes, or found in the decisions of judges. There is a wide range of implications that the law can then accord to these principles. They can be relied on to invalidate legislation, constrain the actions of the executive branch, or they be used as interpretive tools where the law is otherwise unclear.

The presence of these principles within the constitution gives us a reason to care about their interpretation. Those within the constitution are already committed to upholding the principle: demonstrating that a better interpretation of the principle is available may - should - shift their understanding of its requirements. The place of the rule of law within the Chinese constitution provides a powerful example of the potential force of principles. The embrace of the rule of law within China has made a difference to the lives of Chinese people, with an emerging system of administrative law shaping the conduct of the bureaucracy. ${ }^{34}$ A difficult, and currently debated, question in China surrounds the role that the Party plays in deciding sensitive cases

\footnotetext{
33 R. Hazell, 'The Continuing Dynamism of Constitutional Reform' (2007) Parliamentary Affairs 3; D. Woodhouse, 'The Constitutional and Political Implications of a United Kingdom Supreme Court' (2004) 24 Legal Studies 134; D. Pannick, 'Replacing the Lords By a Supreme Court' [2009] Public Law 723 .

34 Q. Zhang, The Constitution of China: A Contextual Analysis (Oxford: Hart, 2012), chapter 5.
} 
and judicial independence. By showing the part that judicial independence plays in the rule of law, reforms to China's judicial system can be presented as a working through of a principle to which the constitution is already committed; rather than the reforms being imposed upon the Chinese system from the outside, these are values that are inherent to that order.

Those who are sceptical of the analytical value of these principles should be careful not to overlook their practical utility. Even if it is possible to reason directly from values to institutional structure, the broad popular support that these principles enjoy may justify debates over their implication and content.

Secondly, and perhaps relatedly, because the principles of constitutionalism play a mediating role between values and institutional structure, their claims can sometimes prove less controversial than arguments based directly on values. There may be a number of different values that justify a particular institutional arrangement. This may mean that people can disagree over the connection between any given value and an institutional structure, but still agree on the attractions of the principle. ${ }^{35}$ Indeed, a further benefit of reasoning through principles is that these principles combine a number of related institutional features, presenting them as a package. Accepting one element might lead a person to accept other features as well. So, for example, a person who is committed to democracy would also be led to endorse elements of the separation of powers - for democracy to function properly, an independent judiciary and a capable executive branch are required. But the path might also run in the other direction. A person who was committed to judicial independence because she valued legal certainty might also come to recognise the role that a democratically elected legislature can play in guaranteeing judicial independence - both by providing a line of protection between the courts and the executive, and by taking some politically controversial decisions out of the hands of the judges. The principles of constitutionalism are animated by a range of values, but they present themselves as forming a coherent whole, both within each principle and between the elements of constitutionalism more broadly.

35 See C. Sunstein, 'Incompletely Theorized Agreements' (1995) 108 Harvard Law Review 1733. 
A successful account of constitutionalism would also enhance our understanding of the state. All of the principles of constitutionalism find their origins in the characteristic purpose of the state: the advancement of the well-being of its people. As such, they amount to a working through of this claim. To achieve its goals, the state must adhere to these principles. A good state, a state that is a successful state, will possess an institutional structure that is characterised by constitutionalism. An account of constitutionalism enhances our understanding of the state by explaining the form that the state should take. Furthermore, to an extent, some of the principles of constitutionalism must be honoured in order for the state to exist. Sovereignty relates to the authority claims that all states make over people and territories. A polity that did not assert sovereignty or which could not, to some degree, make good on these claims would not be a state. Similarly, for the state to be able to exercise authority some aspects of the separation of powers and rule of law must be present: states require law in order to exert control within their territories. An understanding of constitutionalism is not, then, merely a development of an account of the state, it is a refinement of that account: a clarification of the nature of the state.

\section{CONCLUSION}

This paper has sought to provide constitutionalism with a fresh start, but a fresh start that is faithful to older work on the doctrine. The negative model of constitutionalism is an impoverished version of the doctrine, which may find its origins in an impoverished understanding of the state. This account treats the state as a threat to the wellbeing of its people, and constitutionalism as a set of constraints that seek to mitigate that threat. A richer account of the state, one that recognises its role in advancing the wellbeing of its people, generates a richer account of constitutionalism. This positive model of constitutionalism acknowledges the need for constitutional structures to guard against abuses of power - it is not utopian - but is focused on creating a strong state able to work for the good of its people. Positive constitutionalism contains a range of principles - the separation of power, state sovereignty, subsidiarity, and so forth - that help determine the institutional structure of the state and the constitutional interaction of these institutions. A line can be 
traced from the institution of the state as a whole, through the doctrine of constitutionalism, to the discrete principles of constitutionalism, and then back to the internal institutional structure of the state. 